\title{
A Study on the Relationship between Board Characteristics and Corporate Performance of Listed Companies in China
}

\author{
Xiaofeng Tian \\ College of Management \\ Wuhan University of Science and Technology \\ Hubei, China
}

\author{
Wenting Nie \\ College of Management \\ Wuhan University of Science and Technology \\ Hubei, China \\ 545945218@qq.com
}

\begin{abstract}
In modern corporate governance, the separation of ownership and management right results in the increasing rise of contradictions between company management level and shareholders. Internal governance problem receives much attention. Board characteristic is one of the cores of corporate governance, so the board has been an important research topic of domestic and overseas scholars. The influence of board characteristics of listed companies in China on corporate performance is mainly discussed in this paper. Studying the influence of board characteristics on corporate performance contributes to improving corporate governance level. Relevant data of Chinese listed A-share companies in $\mathbf{2 0 1 5}$ were used as the object of study. Corporate performance was measured with the return on assets by applying regression analysis method. The relationship between board characteristics and corporate performance was investigated from two aspects including the board size and the proportion of board independence. The results show that firstly, proper expansion of board scale is beneficial to improve corporate performance. In other words, significant positive correlation exists between the board size and corporate performance; secondly, the increase in the proportion of independent directors contributes to improving corporate governance level, that is, board independence is positively related to corporate performance.
\end{abstract}

Keywords-board characteristics; corporate performance; listed companies.

\section{INTRODUCTION}

With economic development and continuous improvement of securities market, the governance of listed companies has received more and more attention. The board plays an important role in decision making and supervision process of listed companies, and it is the core of corporate governance. Besides, the board is not just the agent, but also the mandator. The existence of board can reduce corporate agency cost. Hence, an increasing number of scholars have studied the relationship between board characteristics and corporate performance. At present, many domestic and overseas scholars have researched the relationship between the two, but there is no consistent conclusion. As the number of listed companies rises in China, it is increasingly necessary to research the relationship between board characteristics and corporate performance. This paper will study the relationship between board characteristics and corporate performance by taking Chinese listed A-share companies in 2015 as the object of study, in the hope of providing certain experience for improving board characteristics and then promoting corporate performance.

\section{LITERATURE REVIEW}

\section{A. Board size and corporate performance}

Foreign scholars studied the relationship between board characteristics and corporate performance early. Lipton and Lorsch (1992) believed that the proper control of board size is most beneficial to corporate development, because the board with a large size could effectively supervise the enterprise, but the over-large board size will lead to the rise of communication and coordination cost, which is adverse to corporate development ${ }^{[1]}$. Kiel and Nicholson (2003) found that the board size is positively related to corporate performance. Some scholars also hold different opinions. Andres, Azofra and Lopez (2005) took the developed countries as the object of study and found that the relationship between the board size and corporate performance is not the single linear relation, but presents $U$ shape $^{[2]}$.

Chinese scholars lag far behind foreign scholars in terms of the research on the relationship between board characteristics and corporate performance. In recent years, numerous researches have been done by Chinese scholars, but no consistent conclusion is reached like foreign scholars. Fan Linbang (2010) thought that there is no significance between board characteristics and corporate performance. Chen Ding and Zhang Shun (2010) considered that the board size is positively related to corporate performance. Some scholars believe that the expansion of board size is adverse to corporate development. Liu Li (2002) took Chinese iron and steel industry as the object of study and found that the board size is negatively related to corporate performance. For the research on the relationship between the board size and corporate performance, there are different views, except the above two conclusions. Zhao Dang (2012) and Shi Talin (2014) held that an inverted U-shaped relation exists between the board size and corporate performance ${ }^{[3]}$. 


\section{B. The proportion of independent directors and corporate performance}

There is no consistent conclusion abroad about the influence of proportion of independent directors on corporate performance. Butler (1994) measured corporate performance with the net return on assets and found that corporate performance improves after the increase in the proportion of independent directors. Dahya \& McConnell (2005) deeply analyzed the listed companies in which the number of independent directors was 3 or above and discovered that corporate performance improves significantly after the increase in the number of independent directors, and the operation cost also decreases. Thus, they considered that the proportion of independent directors is positively related to corporate performance. Karpoff and Raheja (2007) found that the proportion of independent directors presents significant negative correlation with ROA of the previous year ${ }^{[4]}$. Apart from these conclusions, some scholars consider no correlation exists between the two. Weisbachc (1997) measured corporate performance with Tobin's Q value and found that corporate performance is not influenced by the proportion of independent directors.

Chinese scholars also hold different opinions on the relationship between the two. Research findings of Chen Jun (2006) show that the increase in the number of independent directors can improve corporate performance. Gong Huifeng (2011) considered that the proportion of independent directors presents significant positive correlation with corporate performance ${ }^{[5]}$. Gou Zhixia (2008) indicated that the proportion of independent directors is negatively related to corporate performance. Liu Yazheng (2009) also thought the increase in the proportion of independent directors hinders corporate development. Chen Lufei (2012) studied the relationship between board characteristics of GEM Listed companies and corporate performance and found that the relationship between the proportion of independent directors and corporate performance presents an inverted U-shaped relation ${ }^{[6]}$. Yang Dian (2013) argue that there is no significant correlation between the proportion of outside directors and corporate performance relationship ${ }^{[7]}$.

\section{THEORETICAL ANALYSIS AND RESEARCH HYPOTHESIS}

\section{A. Board size and corporate performance}

The expansion of board size can't just enhance the supervision of directors in the board, but also supervise the behaviors of top management level. The over-small board size will limit corporate development, while many directors can bring different knowledge for the enterprise. Different directors own their own knowledge and experience. Most importantly, they have their own network of relations. Hence, more directors can introduce more resources for the enterprise to reduce corporate operation risks and thus improve corporate governance level. Therefore, the increase in the board size is beneficial to corporate development. On this basis, the following hypotheses are proposed:

H1: The board size and corporate performance are positively related.

\section{B. The proportion of independent directors and corporate performance}

After an enterprise develops and expands, it will be faced with the separation of enterprise ownership and control right. A very important issue in corporate governance is to make sure the operators do not violate the will of owners, and to reduce agency cost. The proportion of independent directors reflects objectivity, expertise and independence of the board to certain degree. Different directors represent the interests of different shareholders. The board can coordinate the relationship between operators and shareholders. Independent directors can supervise and counterbalance operators' decisions, promote the interests of operators and owners to reach consistency, reduce the problems of internal control, improve corporate operation efficiency and maintain the interests of some minority shareholders The higher proportion of independent directors is more beneficial to corporate development.

$\mathrm{H} 2$ : The proportion of independent directors is positively related to corporate performance.

\section{EMPIRICAL TEST OF THE RELATIONSHIP BETWEEN BOARD CHARACTERISTICS AND CORPORATE PERFORMANCE}

\section{A. Sample selection}

A-share companies listed in Shanghai and Shenzhen in 2015 were chosen as the object of study, and the data about board characteristic data and corporate performance were collected. The companies with ST, PT and *ST were rejected. Besides, the companies without the complete data were eliminated. Finally, 2750 effective observation data were left. All data come from CSMAR database. Excel and STATA14.0 will be applied for empirical analysis.

\section{B. Research variables}

Explained variable. In this paper, ROA is chosen to measure corporate performance. ROA can well reflect corporate profitability. Larger ROA means better corporate performance.

Explanatory variables. The board size (BS) and the proportion of independent directors (IDP) are chosen as the independent variables. The number of directors of listed companies is used to measure the board size, while the proportion of independent directors is expressed with the number of independent directors/the number of all directors. The definition of each variable is as follows:

TABLE I. VARIABLE SPECIFIES

\begin{tabular}{|c|c|c|c|}
\hline Variable & Definition & Meaning & Sign \\
\hline $\begin{array}{c}\text { Explained } \\
\text { variable }\end{array}$ & Return on assets & Profit/ total assets & ROA \\
\hline $\begin{array}{c}\text { Explanatory } \\
\text { variable }\end{array}$ & Board size & The number of directors & BS \\
\hline $\begin{array}{c}\text { Explanatory } \\
\text { variable }\end{array}$ & $\begin{array}{c}\text { The proportion of } \\
\text { independent directors }\end{array}$ & $\begin{array}{c}\text { The number of independent } \\
\text { directors / the number of all } \\
\text { directors }\end{array}$ & IDP \\
\hline
\end{tabular}


Modeling. To test the above hypotheses, regression models are designed as follows:

$$
\begin{aligned}
& \mathrm{ROA}=\alpha+\beta 1 \mathrm{BS}+\varepsilon \\
& \mathrm{ROA}=\alpha+\beta 2 \mathrm{IDP}+\varepsilon
\end{aligned}
$$

\section{Descriptive statistics and regression analysis}

As shown in the following table, BS represents the board size. We can see that the board size differs a lot. The minimum value is 0 . This indicates that some companies do not accord with the board size, which means the governance structure of listed companies still needs improving. The proportion of independent directors is expressed with IDP. We can see form the following table that the maximum value of IDP is 0.8 and the minimum value is 0.2 , with the mean value of 0.3768 . It is stipulated that the proportion of independent directors shall exceed 0.33 . This means the independent director system of some listed companies is not sound enough.

TABLE II. DESCRIPTIVE STATISTICS

\begin{tabular}{|c|c|c|c|c|c|}
\hline Variable & $\begin{array}{c}\text { Observed } \\
\text { value }\end{array}$ & $\begin{array}{c}\text { Mean } \\
\text { value }\end{array}$ & $\begin{array}{c}\text { Standard } \\
\text { deviation }\end{array}$ & $\begin{array}{c}\text { Minimum } \\
\text { value }\end{array}$ & $\begin{array}{c}\text { Maximum } \\
\text { value }\end{array}$ \\
\hline ROA & 2750 & 0.0322 & 0.0671 & -0.8996 & 0.4819 \\
\hline BS & 2750 & 8.5949 & 1.8149 & 0 & 18 \\
\hline IDP & 2750 & 0.3768 & 0.0567 & 0.2 & 0.8 \\
\hline
\end{tabular}

\section{Empirical result analysis}

Regression analysis results of sample data are shown in the following table.

(1) The regression coefficient of BS variable is positive, which means BS and corporate performance present changes. According to the table, $\mathrm{P}$ value is 0.000 , which means it passes significance test. Hence, the larger the board size, the better the corporate performance.

(2) We can see from Table 4 that, the correlation coefficient between IDP and corporate performance is positive. This indicates that the two present same direction changes. $\mathrm{P}$ value is 0.000 , which means it passes significance test. This shows that the larger IDP is more beneficial to corporate development, and can improve corporate performance. Thus, $\mathrm{H} 2$ is tenable.

TABLE III. REGRESSION RESULTS OF BS AND CORPORATE PERFORMANCE

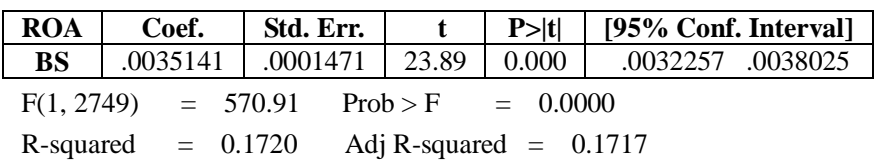

TABLE IV. REGRESSION ANALYSIS RESULTS Of IDP AND CORPORATE PERFORMANCE

\begin{tabular}{|l|c|c|c|c|cc|}
\hline ROA & Coef. & Std. Err. & $\mathbf{t}$ & $\mathbf{P}>|\mathbf{t}|$ & [95\% Conf. Interval] \\
\hline IDP & .0837237 & .0033679 & 24.86 & 0.000 & .0771198 & .0903275 \\
\hline F(1, 2749) $=$ & 617.99 & Prob $>$ F $=0.0000$ \\
R-squared $=0.1836 \quad$ Adj R-squared $=0.1833$
\end{tabular}

\section{CONCLUSION}

\section{A. Research conclusion}

After empirical analysis of board characteristics and corporate performance, the following research conclusions can be drawn:

(1) BS plays a significant positive promotion role for corporate performance. When BS is larger, the board can listen to the views of more experts in the decision making process so that the decisions made by the board will be more rational. Thus, corporate governance efficiency improves. Further, this also contributes to improving corporate performance.

(2) IDP is positively related to corporate performance. If IDP increases, the board will become more effective and better supervise the company and shareholders. Meanwhile, the problems of internal control will decrease. The increase in the number of independent directors makes the decisions made by the board more objective and scientific. And then, corporate operation efficiency will improve.

\section{B. Policy suggestions}

Firstly, the board system of some listed companies in China is not sound enough, so it is required to properly control the board size and give full play to the supervision function of the board.

Secondly, at present, the proportion of independent directors in some companies is relatively low. Thus, it is required to increase properly the proportion of independent directors, accelerate establishment and improvement of independent director system, make the board more effective and prevent the problem of internal control so as to improve corporate governance level and corporate performance.

\section{REFERENCES}

[1] Lipton. M, Lorsch J W. A Modest Proposal for Improved Corporate Governance[J]. Business Lawyer, 1992, 48(1):59-77.

[1] Andres P D, Azofra V, Lopez F. Corporate Boards in OECD Countries: size, composition, functioning and effectiveness[J].Corporate Governance: An International Review, 2005, 13(2):197-210.

[2] Shi Dalin, Han Dongyan, Yang Qiong. The Dynamics Relationship

[3] Between Board Characteristics and Corporate Agency Costs - Based on Dynamic and Endogenous Empirical Research [J]. Journal of Zhengzhou Institute of Aeronautical Industry Management, 2014, 32(2):43-53

[4] Boone. A L, Field L C, Karpoff J M, et al. The determinants of corporate :board size and composition: An empirical analysis [J]. Ssrn Electronic Journal, 2007, 85(1):66-101.

[5] Gong. Huifeng. Empirical Analysis of Listed Company's Board Character and Performance [J]. Commercial Research, 2011, 28(10):56-62

[6] Chen Lufei. Empirical Research on Board Characteristics of GEM. Listed Companies and Corporate Performance [J]. Hainan Finance, 2012(8):59-63.

[7] Yang Dian. Corporate Governance and Firm Performance: A Sociological Analysis Based on Chinese Experience [J]. Social Sciences in China, 2013(1):72-94. 